\title{
Development of $\mathrm{CuO}$-based oxygen carriers supported on diatomite and kaolin for chemical looping combustion
}

Desenvolvimento de transportadores de oxigênio a base de $\mathrm{CuO}$ suportado em diatomita e caulim para combustão por recirculação química

Desarrollo de transportadores de oxígeno a base de $\mathrm{CuO}$ soportado por diatomita y caolín para combustión por recirculación química

Received: 02/10/2021 | Reviewed: 02/14/2021 | Accept: 03/26/2021 | Published: 04/03/2021

Romário Cezar Pereira da Costa

ORCID: https://orcid.org/0000-0002-1488-8536 Universidade Federal do Rio Grande do Norte, Brazil E-mail: romariopfg@ @otmail.com

Rebecca Araújo Barros do Nascimento

ORCID: https://orcid.org/0000-0002-4185-9802 Universidade Federal do Rio Grande do Norte, Brazil E-mail: rebeccaabn@hotmail.com

Dulce Maria de Araújo Melo

ORCID: https://orcid.org/0000-0001-9845-2360 Universidade Federal do Rio Grande do Norte, Brazil E-mail: daraujomelo@gmail.com

Dener Silva Albuquerque

ORCID: https://orcid.org/0000-0003-1892-1783 Universidade Federal do Rio Grande do Norte, Brazil E-mail: dener_rn@yahoo.com.br

Rodolfo Luiz Bezerra de Araújo Medeiros

ORCID: https://orcid.org/0000-0002-3072-1250 Universidade Federal do Rio Grande do Norte, Brazil E-mail: rodolfoluiz@gmail.com

Marcus Antônio de Freitas Melo

ORCID: https://orcid.org/0000-0003-3697-2859 Universidade Federal do Rio Grande do Norte, Brazil E-mail: mafm.ufrn@gmail.com

Juan Adánez

ORCID: https://orcid.org/0000-0002-6287-098X Instituto de Carboquimica, Espanha E-mail: jadanez@icb.csic.es

\begin{abstract}
Chemical Looping Combustion (CLC) technology has emerged as a promising alternative capable of restricting the effects of global warming due to anthropogenic gas emissions, especially $\mathrm{CO}_{2}$, through its inherent capture. This study aims to synthesize and evaluate $\mathrm{Cu}$-based oxygen carriers supported on natural materials such as diatomite and kaolin, through the incipient wet impregnation method for CLC process applications. Oxygen carriers were characterized by $\mathrm{X}$-ray diffraction (XRD), temperature-programmed reduction (TPR), and scanning electron microscopy with surface energy dispersive $\mathrm{x}$-ray spectroscopy (SEM-EDS). The mechanical strength of the two oxygen carrier particles was determined after the sintering procedure resulting in high crushing force. Reactivity of oxygen carriers was evaluated in a thermobalance with $\mathrm{CH} 4$ and $\mathrm{H} 2$ gases. Different reaction pathways were attempted when undergoing the redox cycles: total direct reduction of $\mathrm{CuO}$ to $\mathrm{Cu}^{0}$ for $\mathrm{Cu}-\mathrm{K}$ and partial reduction of $\mathrm{CuO}$ to $\mathrm{Cu}_{2} \mathrm{O}$ and $\mathrm{CuO}$ to $\mathrm{Cu}-\mathrm{D}$. However, the highest reactivity and reaction rate was achieved in $\mathrm{Cu}-\mathrm{D}$ due to the pore structure of diatomite, the chemical composition and the resulting interaction between $\mathrm{CuO}$ and the support. $\mathrm{H}_{2}$ gas reactivity tests showed a higher conversion rate and greater stability between cycles for both oxygen carriers. Thus, the reducible $\mathrm{CuO}$ content present in $\mathrm{Cu}$-Diatomite during the reactivity test with $\mathrm{H}_{2}$ as the fuel gas was ideal for achieving high solids conversion, tendency for greater stability and a higher reaction rate.
\end{abstract}

Keywords: $\mathrm{CO}_{2}$ capture; Chemical looping combustion; Oxygen carriers; Copper; Diatomite; Kaolin.

\section{Resumo}

A tecnologia de Combustão com recirculação química (CLC) surgiu como uma alternativa promissora capaz de restringir os efeitos do aquecimento global devido às emissões de gases antropogênicos, principalmente $\mathrm{CO}_{2}$, por meio de sua captura inerente. Este estudo tem como objetivo sintetizar e avaliar carreadores de oxigênio à base de $\mathrm{Cu}$ suportados em materiais naturais como diatomita e caulim, através do método de impregnação úmida incipiente para 
aplicações em processos CLC. Os portadores de oxigênio foram caracterizados por difração de raios-X (XRD), redução à temperatura programada (TPR) e microscopia eletrônica de varredura com espectroscopia de energia de superfície dispersiva de raios-X (SEM-EDS). A resistência mecânica dos transportadoras de oxigênio foi determinada após o procedimento de sinterização, resultando em alta força de esmagamento. A reatividade dos carreadores de oxigênio foi avaliada em termobalança com os gases $\mathrm{CH}_{4}$ e $\mathrm{H}_{2}$. Diferentes vias de reação foram analisadas durante os ciclos redox: redução direta total de $\mathrm{CuO}$ para $\mathrm{Cu}^{0}$ para $\mathrm{Cu}-\mathrm{K}$ e redução parcial de $\mathrm{CuO}$ para $\mathrm{Cu}_{2} \mathrm{O}$ e $\mathrm{CuO}$ para $\mathrm{Cu}-\mathrm{D}$. No entanto, a maior reatividade e taxa de reação foram alcançadas para o $\mathrm{Cu}$-D devido à estrutura porosa da diatomita, à composição química e à interação resultante entre o $\mathrm{CuO}$ e o suporte. Os testes de reatividade com o gás $\mathrm{H}_{2}$ mostraram uma maior taxa de conversão e maior estabilidade entre os ciclos para ambos os transportadores de oxigênio. Assim, o teor de $\mathrm{CuO}$ redutível presente na $\mathrm{Cu}-\mathrm{D}$ durante o teste de reatividade com $\mathrm{H}_{2}$ como gás combustível foi ideal para obtenção de alta conversão dos sólidos, tendência a maior estabilidade e maior taxa de reação.

Palavras-chave: Captura de $\mathrm{CO}_{2}$; Combustão por recirculação química; Transportadores de oxigênio; Cobre; Diatomita; Caulim.

\section{Resumen}

La tecnología de combustión con transportadores sólidos de oxígeno (CLC) ha surgido como una alternativa prometedora capaz de restringir los efectos del calentamiento global por emisiones de gases antropogénicos, principalmente $\mathrm{CO}_{2}$, a través de su captura inherente. Este estudio tiene como objetivo sintetizar y evaluar transportadores de oxígeno basados en $\mathrm{Cu}$ apoyados en materiales naturales como la diatomita y el caolín, utilizando el incipiente método de impregnación húmeda para aplicaciones en procesos CLC. Los portadores de oxígeno se caracterizaron por difracción de rayos-X (XRD), reducción com temperatura programada (TPR) y microscopía electrónica de barrido con espectroscopía de energía superficial dispersiva de rayos-X (SEM-EDS). La resistencia mecánica de los portadores de oxígeno se determinó después del procedimiento de sinterización, lo que resultó en una alta fuerza de trituración. La reactividad de los portadores de oxígeno se evaluó en termobalance con los gases $\mathrm{CH}_{4}$ y $\mathrm{H}_{2}$. Se analizaron diferentes vías de reacción durante los ciclos redox: reducción total directa de $\mathrm{CuO}$ a $\mathrm{Cu}{ }^{0} \mathrm{para} \mathrm{Cu}-\mathrm{K}$ y reducción parcial de $\mathrm{CuO}$ a $\mathrm{Cu}_{2} \mathrm{O}$ y $\mathrm{CuO}$ para $\mathrm{Cu}-\mathrm{D}$. Sin embargo, la mayor reactividad y velocidad de reacción se logró para Cu-D debido a la estructura porosa de la diatomita, la composición química y la interacción resultante entre $\mathrm{CuO}$ y el soporte. Las pruebas de reactividad con gas $\mathrm{H}_{2}$ mostraron una mayor tasa de conversión y una mayor estabilidad entre ciclos para ambos transportadores de oxígeno. Así, el contenido reducible de $\mathrm{CuO}$ presente en $\mathrm{Cu}-\mathrm{D}$ durante la prueba de reactividad con $\mathrm{H}_{2}$ como gas combustible fue ideal para obtener una alta conversión de sólidos, con tendencia a una mayor estabilidad y mayor velocidad de reacción.

Palabras clave: Captura de $\mathrm{CO}_{2}$; Combustión con transportadores sólidos de oxígeno; Transportadores de oxigênio; Diatomita; Caolín.

\section{Introduction}

Sustainability is one of the most important and necessary challenges for societies today. However, the climate change being suffered by the planet should be a warning to this factor. Carbon dioxide $\left(\mathrm{CO}_{2}\right)$ is a long-lived anthropogenic gas in the atmosphere and there is an intensification of the effects of global warming due to its progressive emission from fossil fuel combustion processes (Takht \& Saeed, 2014; Fernandes et al., 2019; Oliveira et al., 2020; Gomes et al., 2021). The Paris Agreement was established in order to limit these effects, requiring the decarbonization of the world's energy systems, limiting the average global temperature increase to $2{ }^{\circ} \mathrm{C}$ for the next century. In order to achieve this goal, Chemical Looping Combustion (CLC) has emerged as a promising technology for $\mathrm{CO}_{2}$ capture in power plants and industrial applications with low energy penalty compared to other competing $\mathrm{CO}_{2}$ capture and storage (CCS) technologies (Adánez-Rubio et al., 2018; Adánez et al., 2018; McGlashan et al., 2012; Wang, Yan et al., 2018). 
Figure 1. Basic scheme of CLC process.

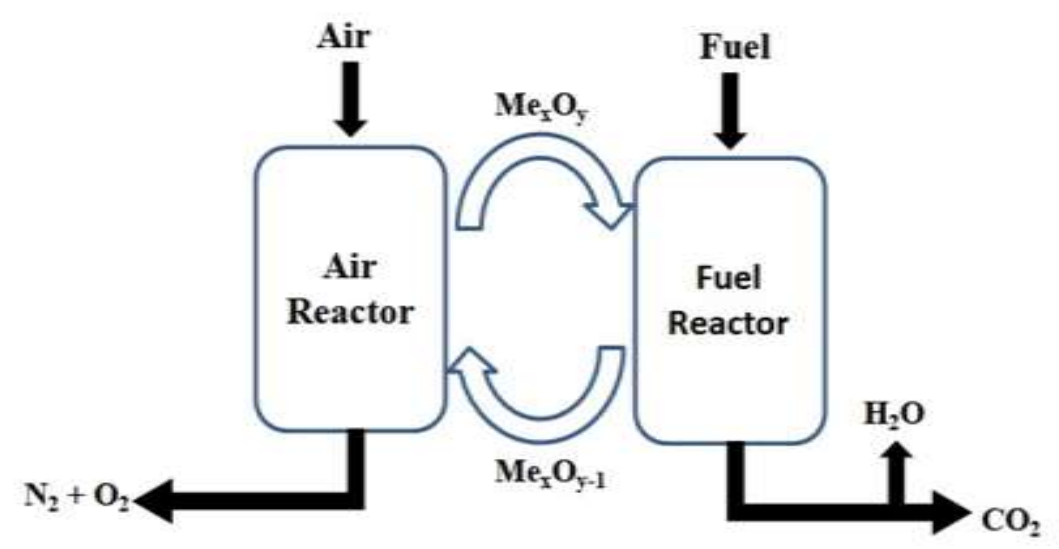

Source: Adapted from Adanez et al. (2012).

The Figure 1 show the CLC technology. This system describes cyclic redox processes between two interconnected reactors and is based on the use of a metal oxide $\left(\mathrm{M}_{\mathrm{x}} \mathrm{O}_{\mathrm{y}}\right)$, known as an oxygen carrier $(\mathrm{OC})$, to transfer the required oxygen from the air (Reaction 1) and oxidize the fuel to $\mathrm{CO}_{2}$ and $\mathrm{H}_{2} \mathrm{O}$ (Reaction 2) to avoid direct contact between the air and fuel. Its main advantage is the inherent capture of $\mathrm{CO}_{2}$, bypassing the energy penalty. Finding oxygen carriers with good physicochemical properties is the critical point for CLC technologies. OCs require high fuel reactivity, excessive oxygen carrying capacity, high friction and agglomeration resistance, low toxicity and low cost (Zhang et al., 2019). Based on these characteristics, Adanéz and colleagues (Adanez et al., 2012) reviewed possible $\mathrm{Ni}, \mathrm{Fe}, \mathrm{Cu}, \mathrm{Co}$ and $\mathrm{Mn}$ oxides and probable inert materials as supports, for example $\mathrm{SiO}_{2}, \mathrm{Al}_{2} \mathrm{O}_{3}, \mathrm{TiO}_{2}, \mathrm{ZrO}_{2}$, to improve the reactivity and life time of oxygen carriers.

$\mathrm{Me}_{\mathrm{x}} \mathrm{O}_{\mathrm{y}-1}+1 / 2 \mathrm{O}_{2} \rightarrow \mathrm{Me}_{\mathrm{x}} \mathrm{O}_{\mathrm{y}}$

(Reaction 1)

$(2 \mathrm{n}+\mathrm{m}) \mathrm{Me}_{\mathrm{x}} \mathrm{O}_{\mathrm{x}}+\mathrm{C}_{\mathrm{n}} \mathrm{H}_{2 \mathrm{~m}} \rightarrow(2 \mathrm{n}+\mathrm{m}) \mathrm{Me}_{\mathrm{x}} \mathrm{O}_{\mathrm{y}-1}+\mathrm{mH}_{2} \mathrm{O}+\mathrm{nCO}_{2}$

(Reaction 2)

In addition, there is great flexibility in fuel characteristics, making the use of gaseous, liquid and solid fuels viable. The use of solid fuels such as coal and biomass has been of great interest, as coal will continue to be an important source of energy in the medium term, generating neutral emissions (Takht \& Saeed, 2014). Moreover, the use of biomass waste triggers negative emissions due to the intrinsic balance of biomass combined with $\mathrm{CO}_{2}$ capture and storage techniques (Bioenergy with Carbon Capture and Storage - BECCS) (Adánez et al., 2018; Mendiara et al., 2018).

In-Situ Gasification Chemical Looping (iG-CLC) and Chemical Looping with Oxygen Uncoupling (CLOU) are proposed solid fuel CLC processes in which gas-solid reactions occur. In iG-CLC technology, solid fuel is first gasified in situ to synthesis gas $\left(\mathrm{CO}+\mathrm{H}_{2}\right)$ and this reacts with the OC in the fuel reactor (Wang et al., 2018). On the other hand, the CLOU process requires a suitable oxygen carrier capable of reversibly releasing $\mathrm{O}_{2(\mathrm{~g})}$, having oxygen equilibrium partial pressure at high temperatures (800-1000 ${ }^{\circ} \mathrm{C}$ ), for example, $\mathrm{CuO}, \mathrm{Mn}_{2} \mathrm{O}_{3}$ and $\mathrm{Co}_{3} \mathrm{O}_{4}$ ( $\mathrm{Abad}$ et al., 2012; Adánez-Rubio et al., 2017; Gayán et al., 2012). In this case, solid fuel is burned by gaseous oxygen which is decoupled from the $\mathrm{OC}$ in the fuel reactor. The main advantage of the CLOU process over the iG-CLC is that direct burning of solid fuel promotes faster combustion as it eliminates the slow coal gasification step (Abad et al., 2012; Adánez-Rubio et al., 2013; Adánez-Rubio et al., 2017).

Cu-based oxygen carriers were reviewed and studied by (Adánez-Rubio et al., 2013; Adánez-Rubio et al., 2011; Adanez et al., 2012; de Diego et al., 2005; Forero et al., 2009), and showed high reactivity, high reaction rates, and oxygen carrying capacity, and did not show thermodynamic restrictions for complete conversion of fuel to $\mathrm{CO}_{2}$ and $\mathrm{H}_{2} \mathrm{O}$. In combining with inert supports such as $\mathrm{Al}_{2} \mathrm{O}_{3}$, bentonite, $\mathrm{MgO}, \mathrm{MgAl}_{2} \mathrm{O}_{4}, \mathrm{SiO}_{2}$, and $\mathrm{TiO}_{2}$, it is possible to achieve an OC with high mechanical stability and low friction rate. However, problems with agglomeration is a potential issue due to the low melting 
temperature of the $\mathrm{Cu}^{0}\left(1085^{\circ} \mathrm{C}\right)$. Thus, iG-CLC and CLOU can be used with different parameters to prevent this problem. In the CLOU approach, the present redox system is $\mathrm{CuO} / \mathrm{Cu}_{2} \mathrm{O}$ according to Reaction 3 in order to avoid generating metallic $\mathrm{Cu}$, so that high temperatures are used $\left(900-950{ }^{\circ} \mathrm{C}\right)$ due to the $\mathrm{Cu}_{2} \mathrm{O}\left(1235^{\circ} \mathrm{C}\right)$ melting temperature, and therefore the OC has a higher $\mathrm{CuO}$ content. In the iG-CLC process, the approached redox system is $\mathrm{CuO} / \mathrm{Cu}$ according to Reactions 4-5, but the OC has lower $\mathrm{CuO}$ content $(\leq 21 \mathrm{wt} \%)$ and low reaction temperature $\left(\leq 850{ }^{\circ} \mathrm{C}\right)$ due to the melting temperature of $\mathrm{Cu}\left(1083{ }^{\circ} \mathrm{C}\right)$ (Wang et al., 2018).

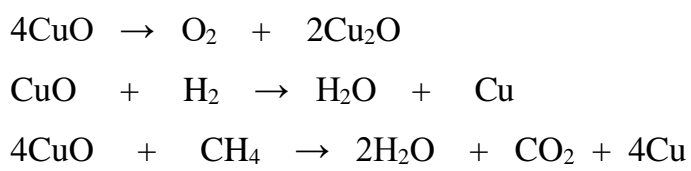

In addition, the use of $\mathrm{Cu}$-based synthetic oxygen carriers with chemical composition and controllable physical structure is expensive and difficult to produce (Zhang et al., 2019). Thus, a natural support such as diatomite and kaolin which have high mechanical strength, high porosity, high availability in Brazil and low cost, is of interest as supports for CLC applications in fluidized bed reactors due to their highly open porous structure in combination with their high mechanical properties, minimizing the cost of developing large-scale Cu-based oxygen carriers (Liu et al., 2019; Van Garderen et al., 2012; Van Garderen et al., 2014). It is also important to consider that both materials are mainly composed of $\mathrm{Al}_{2} \mathrm{O}_{3}$ and $\mathrm{SiO}_{2}$, and the proportion of these two phases in these materials vary, which opens a discussion about the different types of materials which can be formed when subjected to temperatures above $900{ }^{\circ} \mathrm{C}$ (De Freitas et al., 2011; McGlashan et al., 2012; Pio et al., 2018; Pio et al., 2016; Santos et al., 2017).

Song et al. (2014) synthesized commercially supported silica and alumina oxygen carriers by the dry impregnation method and significant differences were observed in the $\mathrm{CuO}$ conversion rate and cycle stability in operation at $950{ }^{\circ} \mathrm{C}$ (Song et al., 2014). However, Van Garderen et al. (2014) investigated the performance of CuO-based OC supported on a range of substrates with different macropore $\left(\mathrm{SiO}_{2}\right)$ and mesopore $\left(\gamma-\mathrm{Al}_{2} \mathrm{O}_{3}\right)$ combinations, and concluded that $\mathrm{CuO}$ supported on a combination of mesopores and macropores have better redox performance compared to synthetic supports with a single pore size distribution (Van Garderen et al., 2014). In this perspective, the purpose of this work is to evaluate the influence of natural supports (kaolin and diatomite) as sources of silica and alumina on the reactivity of $\mathrm{Cu}$-based oxygen carriers obtained through incipient wet impregnation, aiming toward its use in CLC processes with solid fuels.

\section{Methodology}

\subsection{Preparation of the Oxygen Carriers}

The $\mathrm{Cu}$ oxygen carriers used in this work were prepared by incipient wet impregnation using $\mathrm{Cu}\left(\mathrm{NO}_{3}\right)_{2} \cdot 3 \mathrm{H}_{2} \mathrm{O}$ (VETEC, PA $=99 \%$ ) and kaolin and diatomite natural materials collected in the state of Rio Grande do Norte, Brazil, in the particle size range 100-300 $\mu$ to be used as supports. Gayán et al. (2012) studied the incipient wet impregnation technique, which consists of obtaining a more concentrated nitrate solution of the metal to be impregnated (active phase). For this, a saturated solution of metallic nitrate at $80^{\circ} \mathrm{C}$ is prepared, where the solute is dissolved in its own hydration water, in order to obtain a greater amount of solute per unit volume. The mass of the hydrated salt is weighed in the balance, after dissolving the salt at $80^{\circ} \mathrm{C}$ we obtain the final volume and, thus, the concentration of the copper nitrate solution (Gayán et al., 2012).

Gayán et al. (2012) studied the incipient wet impregnation technique, which consists of obtaining a more concentrated nitrate solution of the metal to be impregnated (active phase). For this, a saturated solution of metallic nitrate at $80{ }^{\circ} \mathrm{C}$ is prepared, where the solute is dissolved in its own hydration water, in order to obtain a greater amount of solute per unit volume. 
The mass of the hydrated salt is weighed in the balance, after dissolving the salt at $80^{\circ} \mathrm{C}$ we obtain the final volume and, thus, the concentration of the copper nitrate solution (Gayán et al., 2012).

Wang et al. (2017) found that the formation of $\mathrm{Cu}^{0}$ provides an agglomeration of $\mathrm{Cu}$-based OCs in the CLC process. However, this problem can be avoided by using a low CuO content (Wang et al., 2017). Thus, the mass fraction used was below $20 \%$ wt $\mathrm{CuO}$. The impregnation procedure consisted of mechanically mixing a $5 \mathrm{M}$ copper nitrate solution with the porous supports at $80^{\circ} \mathrm{C}$. Three impregnations were performed on each material to achieve the desired mass fraction, yielding a final volume of $0.42 \mathrm{~mL}$ and $0.30 \mathrm{~mL}$ of $\mathrm{Cu}\left(\mathrm{NO}_{3}\right)_{2} \cdot 3 \mathrm{H}_{2} \mathrm{O}$ per gram of Kaolin and Diatomite, respectively. There was a heat treatment at $550{ }^{\circ} \mathrm{C} / 1 \mathrm{~h}$ after each of the first two impregnations, but the samples were calcined at $1100{ }^{\circ} \mathrm{C} / 1 \mathrm{~h}$ at the end of the last impregnation with the objective of achieving high mechanical strength.

Table 1. Properties of Cu-based oxygen carriers.

\begin{tabular}{|c|c|c|c|c|c|c|c|}
\hline \multicolumn{2}{|c|}{ Suport } & \multicolumn{6}{|c|}{ OCs } \\
\hline & Oxides (\%) & & Oxides (\%) & $\begin{array}{l}\mathrm{CuO} \\
\text { reducible (\%) }\end{array}$ & $\begin{array}{l}\text { Phase } \\
\text { (DRX) }\end{array}$ & $\mathbf{R}_{\mathbf{o c}}$ & $\begin{array}{l}\text { Mechanical } \\
\text { strength (N) }\end{array}$ \\
\hline Kaolin & $\begin{array}{c}50.10 \% \mathrm{SiO}_{2} \\
48.91 \% \mathrm{Al}_{2} \mathrm{O}_{3} \\
0.67 \% \mathrm{~K}_{2} \mathrm{O} \\
0.214 \% \mathrm{Fe}_{2} \mathrm{O}_{3}\end{array}$ & $\mathrm{Cu}-\mathrm{K}$ & $\begin{array}{c}12.92 \% \mathrm{CuO} \\
37.27 \% \mathrm{SiO}_{2} \\
48.81 \% \mathrm{Al}_{2} \mathrm{O}_{3}\end{array}$ & $12.58 \%$ & $\begin{array}{c}\mathrm{CuO}, \mathrm{SiO}_{2}, \\
\mathrm{Al}_{2} \mathrm{SiO}_{5}\end{array}$ & 2.53 & 2.33 \\
\hline Diatomite & $\begin{array}{c}67.55 \% \mathrm{SiO}_{2} \\
31.03 \% \mathrm{Al}_{2} \mathrm{O}_{3} \\
0.77 \% \mathrm{~K}_{2} \mathrm{O} \\
0.429 \% \mathrm{Fe}_{2} \mathrm{O}_{3}\end{array}$ & $\mathrm{Cu}-\mathrm{D}$ & $\begin{array}{c}22.85 \% \mathrm{CuO} \\
57.57 \% \mathrm{SiO}_{2} \\
19.58 \% \mathrm{Al}_{2} \mathrm{O}_{3}\end{array}$ & $18.94 \%$ & $\begin{array}{c}\mathrm{CuO}, \mathrm{SiO}_{2}, \\
\mathrm{Al}_{2} \mathrm{O}_{3}\end{array}$ & 3.81 & 2.96 \\
\hline
\end{tabular}

Source: Authors (2021).

The composition of calcined $\mathrm{Cu}$ samples was determined by $\mathrm{X}$-ray Fluorescence. Table 1 shows the XRF analysis results of the supports and $\mathrm{OC}$, including their main properties.

\subsection{Characterization of the Oxygen Carriers}

Physical and chemical characterization was performed on oxygen carrier particles. The chemical composition of the samples was determined by X-Ray Fluorescence on a Shimadzu Rayny 720 targeting an Rh anode, $50 \mathrm{kV}$ voltage, Si/Li detector. The identification of the crystalline chemical phases was performed by X-ray Diffraction (XRD) using a Shimadzu XRD-7000 X-ray diffractometer with Cuk $\alpha$ radiation $(\lambda=1.5409 \AA$ A). The Joint Committee on Power Diffraction Standards was used to designate the crystalline phases. The structure refinement was performed by applying the Rietveld treatment using MAUD software.

The temperature-programmed reduction (TPR) profile of the OCs was evaluated on a Micromeritics AUTOCHEM II 2920 equipped with a TCD (Thermal Conductivity Detector). The analyzes were conducted by varying the temperature from 100 to $900{ }^{\circ} \mathrm{C}$ under $50 \mathrm{~mL} \cdot \mathrm{min}^{-1}$ flow of a $10 \% \mathrm{H}_{2}$ Argon mixture. It was possible to estimate the oxygen carrying capacity of metallic oxides $\left(\mathrm{R}_{\mathrm{O}}\right)$ through the consumption of $\mathrm{H}_{2}$ according to the equations below.

$$
\mathrm{C}_{H_{2}(\mathrm{~mol})}=\mathrm{C}_{\mathrm{H} 2\left(\frac{\mathrm{m}^{\mathrm{g}}}{\mathrm{g}}\right)} \times 1 \mathrm{ml} \times \frac{1 \mathrm{~L}}{1000 \mathrm{~mL}} \times \frac{1 \mathrm{~mol}}{22.4 \mathrm{~L}}
$$


$\mathrm{R}_{\mathrm{O}}=\frac{\mathrm{m}_{\mathrm{oxi}}-\mathrm{m}_{\mathrm{red}}}{\mathrm{m}_{\mathrm{oxi}}}=\frac{\Delta \mathrm{m}}{\mathrm{m}_{\mathrm{oxi}}}$

(Equation 2)

$\Delta \mathrm{m}=\mathrm{C}_{\mathrm{H} 2(\mathrm{~mol})} \times \frac{16 \mathrm{~g}}{\mathrm{~mol}}$

(Equation 3)

$\mathrm{R}_{\mathrm{oc}}=\mathrm{X}_{\mathrm{OC}} \times \mathrm{R}_{\mathrm{o}}$

(Equation 4)

In which: $\mathrm{C}_{H_{2} \text { (mol) }}$ represents the consumption of $\mathrm{H}_{2}$ per mol, $\mathrm{C}_{\mathrm{H} 2}\left(\frac{\mathrm{cm}^{\mathrm{g}}}{\mathrm{g}}\right)$ is the experimentally consumed volume of $\mathrm{H}_{2}, \mathrm{~m}_{\mathrm{oxi}}$ and $\mathrm{m}_{\mathrm{red}}$ is the oxygen carrier mass when fully oxidized and reduced, respectively, $\mathrm{R}_{\mathrm{OC}}$ is the oxygen carrying capacity of materials, $\mathrm{X}_{\mathrm{OC}}$ is the fraction of the active phases present in the carriers. The mechanical strength of the particles was determined using a Shimpo FGN-5X dynamometer by averaging 20 measurements of the force required to fracture the particle. The microstructure and distribution of the $\mathrm{CuO}$ phase within the particles was analyzed by scanning electron microscopy (SEM) on a Zeiss DSM 942 microscope equipped with an Oxford Link-Isis X-ray Dispersive Energy Analyzer (EDX).

\subsection{Oxygen Carrier Reactivity Test}

Reactivity tests of oxygen carriers were performed on a thermogravimetric analyzer (TGA) (CI Eletronics), with experimental setup shown in Figure 2.

Figure 2. Schematic diagram of the experimental thermobalance configuration.

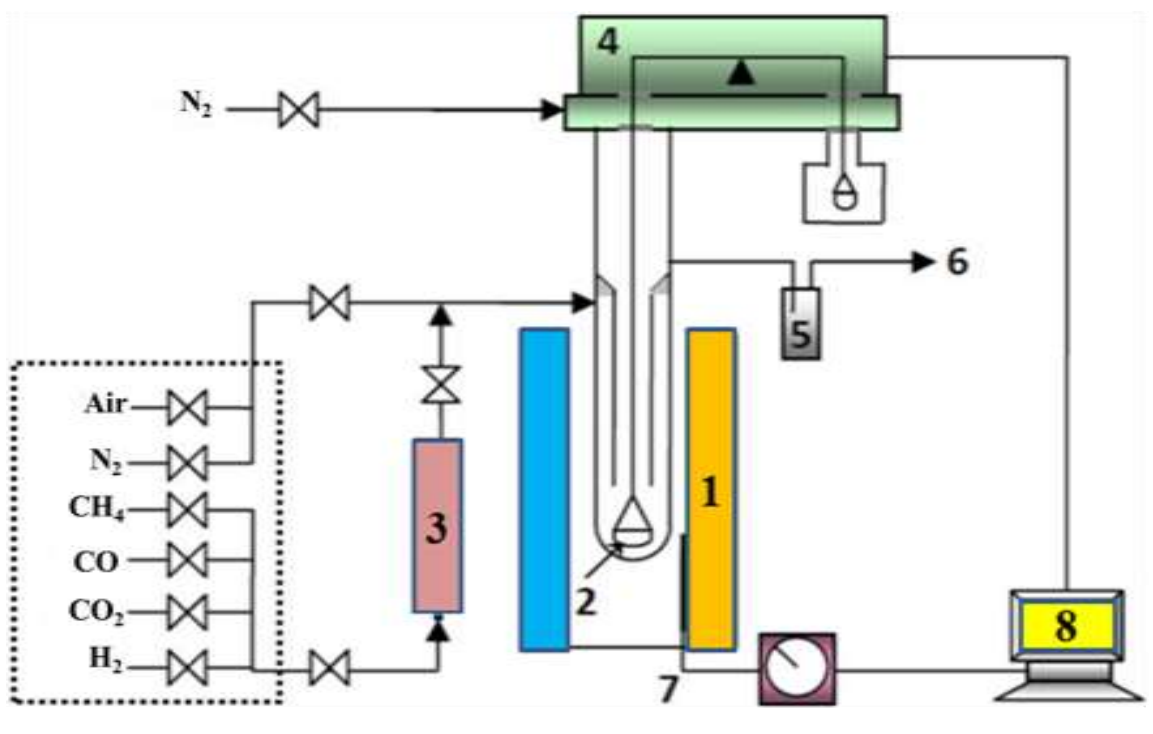

Source: Authors (2021).

In Figura 2: (1) oven; (2) Pt basket with OC; (3) vaporizer; (4) microbalance; (5) condenser; (6) gas outlet; (7) temperature control; and (8) data collector.

In the experiments, $50 \mathrm{mg}$ of the sample was placed in a platinum mesh basket and introduced into a reactor in the form of a quartz tube arranged in an oven operating at a temperature of $950{ }^{\circ} \mathrm{C}$. Upon reaching the operating temperature and system stability, the samples were subjected to the desired reduction and oxidation conditions, alternately and to preserve each step, avoiding reactive gas mixing, and a $\mathrm{N}_{2}$ flow was introduced for $2 \mathrm{~min}$ at the end of each reaction. $\mathrm{CH}_{4}$ and $\mathrm{H}_{2}$ were used as reducing gases, synthetic air as oxidizing gas and nitrogen to purge the system, kept at a flow of $25 \mathrm{~nL} / \mathrm{h}$ throughout the reaction time. The gas composition for the reduction process was $15 \%$ of $\mathrm{CH}_{4}, 20 \% \mathrm{H}_{2} \mathrm{O}, 65 \% \mathrm{~N}_{2}$ or $15 \% \mathrm{H}_{2}, 85 \% \mathrm{H}_{2} \mathrm{O}$, and the gas used for the oxidation process was $100 \%$ air. The temperature and weight of the sample were recorded continuously on 
a computer. It is also important to have a nitrogen flow of $9 \mathrm{~nL} / \mathrm{h}$ to the head in this system, keeping it free of reaction gases, preventing corrosion of the thermobalance electronics.

\section{Results and Discussion}

\subsection{Reactivity of the OCs with $\mathrm{CH}_{4}$ and $\mathrm{H}_{2}$ in the TGA}

Figure $3 a$ and $b$ show the conversion of oxygen carrier as a function of time over three reactivity test cycles in TGA with hydrogen $\left(15 \% \mathrm{H}_{2}+85 \% \mathrm{~N}_{2}\right)$ and methane $\left(15 \% \mathrm{CH}_{4}+20 \% \mathrm{H}_{2} \mathrm{O}+65 \% \mathrm{~N}_{2}\right)$ as fuel.

The conversions obtained by $\mathrm{Cu}-\mathrm{K}$ and $\mathrm{Cu}-\mathrm{D}$ were calculated from the possible redox reactions involved (reactions 611), according to their oxidation degree and in terms of sample weight variation, as shown in Figures $4 a$ and $b$.

$$
\begin{aligned}
& \mathrm{CuO}+\mathrm{H}_{2} \rightarrow \mathrm{H}_{2} \mathrm{O}+\mathrm{Cu} \\
& 2 \mathrm{CuO}+\mathrm{H}_{2} \rightarrow \mathrm{H}_{2} \mathrm{O}+\mathrm{Cu}_{2} \mathrm{O} \\
& \mathrm{Cu}_{2} \mathrm{O}+\mathrm{H}_{2} \rightarrow \mathrm{H}_{2} \mathrm{O}+2 \mathrm{Cu} \\
& 4 \mathrm{CuO}+\mathrm{CH}_{4} \rightarrow 2 \mathrm{H}_{2} \mathrm{O}+\mathrm{CO}_{2}+4 \mathrm{Cu} \\
& \mathrm{Cu}_{2} \mathrm{O}+1 / 2 \mathrm{O}_{2} \rightarrow 2 \mathrm{CuO} \\
& 2 \mathrm{Cu}+\mathrm{O}_{2} \rightarrow 2 \mathrm{CuO}
\end{aligned}
$$

As seen in Figure 4, the largest mass variation for both fuels was obtained with copper oxide supported on diatomite (Cu-D) particles. With $\mathrm{CH}_{4}$ as fuel, it is observed that there is an increase in mass variation over the cycles for $\mathrm{Cu}-\mathrm{K}$. It is also noticeable that the two oxygen carriers showed greater constancy during the three cycles with $\mathrm{H}_{2}$ as fuel. It is reported that the reduction reactions occurred in two steps in both samples; the first when there is only $\mathrm{N}_{2(\mathrm{~g})}$ atmosphere, which involves reactions of the CLOU process, causing the transformation of $\mathrm{CuO} \rightarrow \mathrm{Cu}_{2} \mathrm{O}$, and the second when there is the supply of $\mathrm{H}_{2(\mathrm{~g})}$ or $\mathrm{CH}_{4(\mathrm{~g})}$ as combustible gases. These reactions with the reactive gases are equivalent to the reactions of the iG-CLC process, causing the reduction $\mathrm{CuO} \rightarrow\left(\mathrm{Cu}_{2} \mathrm{O}\right) \rightarrow \mathrm{Cu}^{0}$. Note that the mass loss in the first step related to the CLOU process was higher for $\mathrm{Cu}$-D. Therefore, the experiment was performed at $950{ }^{\circ} \mathrm{C}$ due to the $\mathrm{Cu}_{2} \mathrm{O}$ melting temperature $\left(1235{ }^{\circ} \mathrm{C}\right)$, which is formed during the inert period between oxidation and reduction. 
Research, Society and Development, v. 10, n. 4, e15110412831, 2021

(CC BY 4.0) | ISSN 2525-3409 | DOI: http://dx.doi.org/10.33448/rsd-v10i4.12831

Figure 3. Conversion curves obtained during reactivity test for $\mathrm{Cu}-\mathrm{K}$ and $\mathrm{Cu}-\mathrm{D}$ with a) $\mathrm{H}_{2}$ and b) $\mathrm{CH}_{4}$ as fuels.

A)
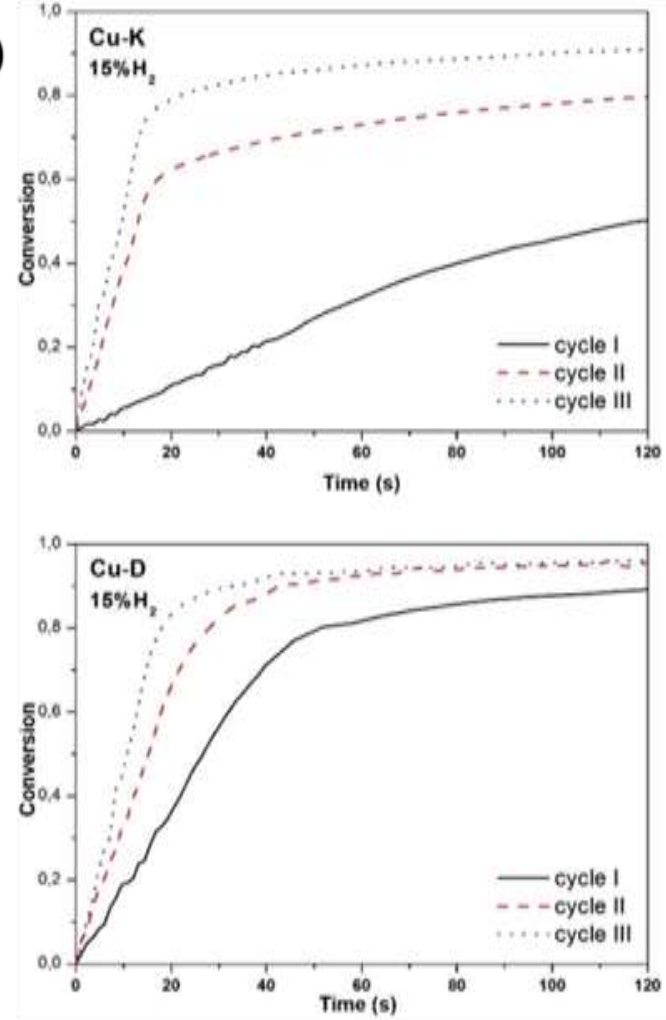

B)
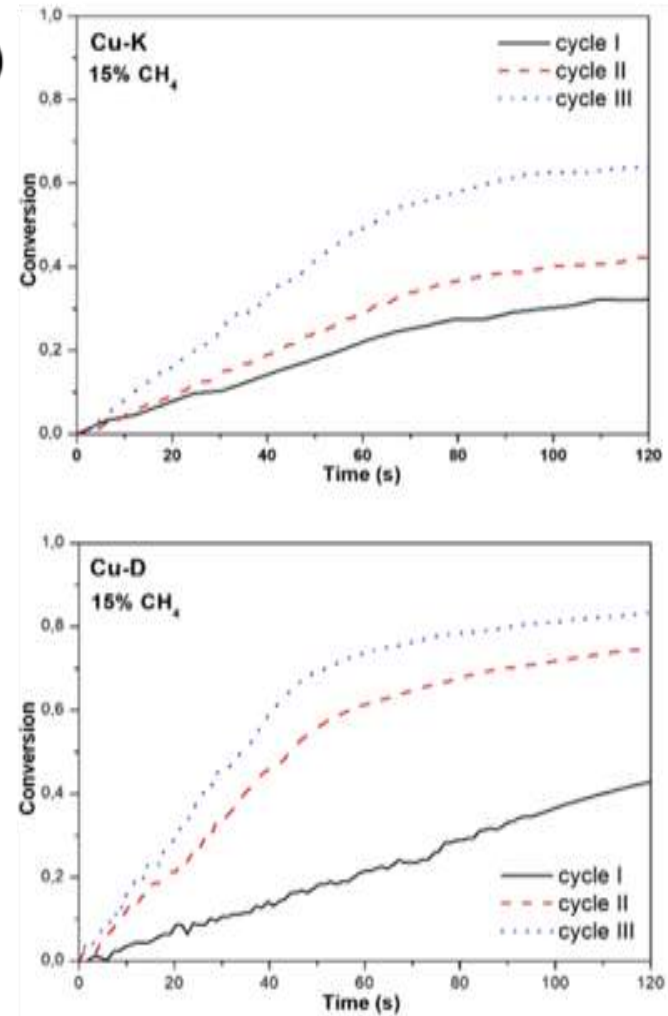
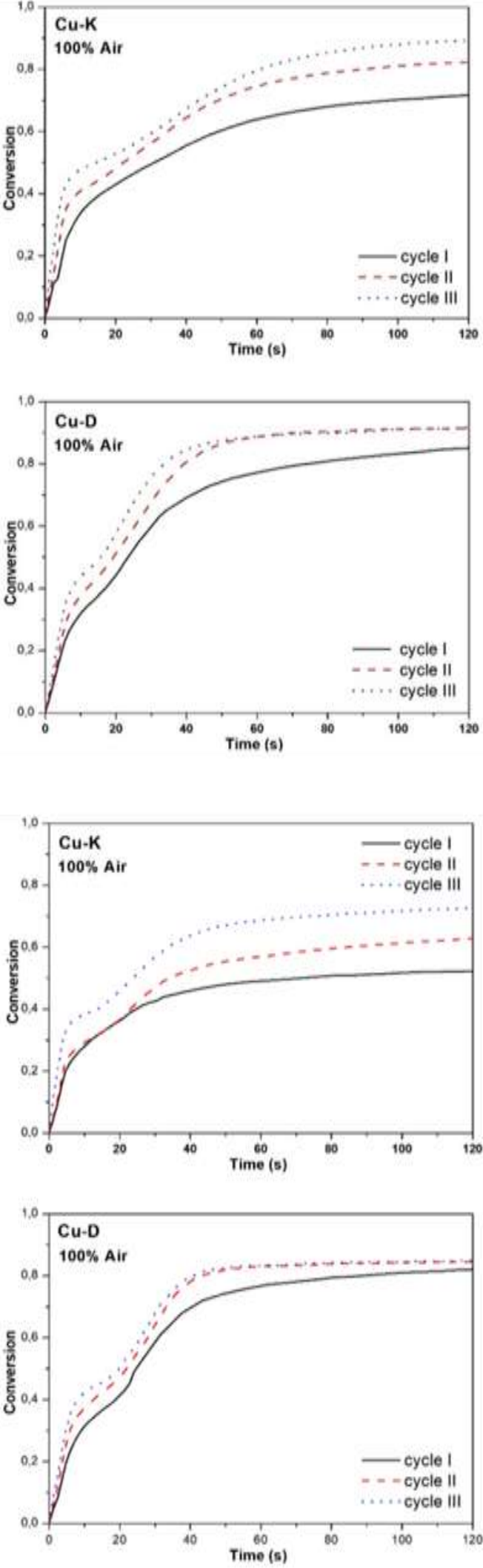

Source: Authors (2021). 
Figure 4. Mass variations during reduction and oxidation reactions for $\mathrm{Cu}-\mathrm{K}$ and $\mathrm{Cu}-\mathrm{D}$ with a) $\mathrm{CH}_{4}$ and b) $\mathrm{H}_{2}$ as fuels.
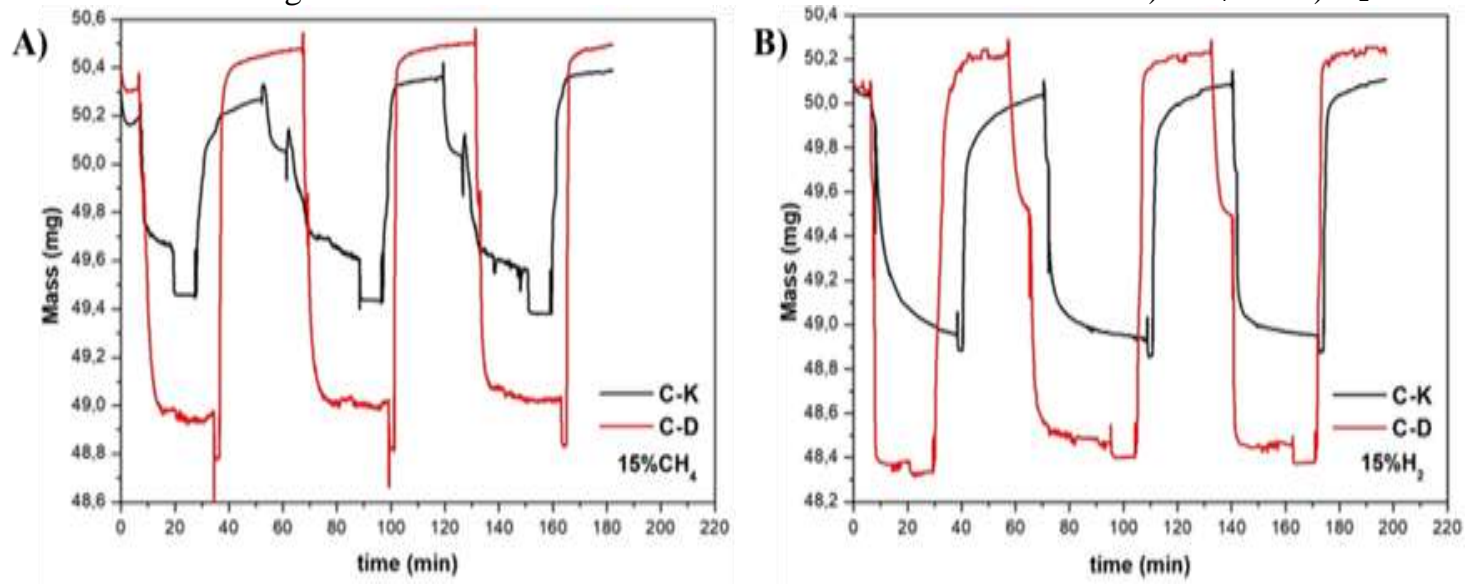

Source: Authors (2021).

The conversion rate calculated for Copper oxide supported on diatomite and kaolin (Figures $3 a$ and $b$ ) shows that there is an increase in reactivity during the three redox cycles, but stability after the third cycle cannot be stated. Early reductions have a slower reaction rate depicting activation of the materials. This is due to the resulting changes in the structure of the fresh oxygen carriers during the first reduction reaction, with the formation of different copper oxides after regeneration in the oxidation step (Wang et al., 2017). The higher reactivity presented by $\mathrm{Cu}-\mathrm{D}$ with $\mathrm{CH}_{4}$ and $\mathrm{H}_{2}$ compared to Cu-K may be due to the porous structure of diatomite, contributing to the reduction of $\mathrm{CuO}$ particle agglomeration, leaving them firm on the surface of this support, and consequently increasing the surface area and its oxygen release capacity. In contrast, $\mathrm{CuO}$ particles in $\mathrm{Cu}-\mathrm{K}$ were free to migrate on the surface, and the three successive cycles show greater differences in reactivity in search of stability.

Through the different inclinations, it is also possible to observe that the $\mathrm{CuO}$ redox process which occurs in diatomite is faster than in the kaolin support. As the microstructure of these two supports is similar, the resulting effect on reactivity and reaction rate is primarily based on variation in chemical composition and the interaction between $\mathrm{CuO}$ and the support (Adánez et al., 2004). But oxygen carriers generally exhibited a higher reaction rate for reduction compared to the reaction rate for oxidation, as noted by Pio et al. (2017), probably due to the diffusive effects inside the oxygen carrier particles. Moreover, a higher reaction rate for gaseous fuel is obtained with $\mathrm{H}_{2}$ than with $\mathrm{CH}_{4}$ in the same concentration (15\%). This can be explained by the reaction stoichiometry, which has a stoichiometry of $1: 1$ with $\mathrm{H}_{2}$, while it is 1:4 with $\mathrm{CH}_{4}$ (Pio et al., 2017).

The evolution of oxygen carrying capacity was evaluated over time for the three cycles, according to Table 2.

Table 2. Oxygen carrying capacity of oxygen carriers during $\mathrm{H}_{2}$ fuel reactivity test.

\begin{tabular}{ccccc}
\hline & & Cycle I & Cycle II & Cycle III \\
\hline \multirow{2}{*}{ Cu-K } & Reduction & 2,43 & 2,48 & 2,53 \\
& Oxidation & 2,43 & 2,58 & 2,59 \\
Cu-D & Reduction & 3,51 & 3,76 & 3,80 \\
& Oxidation & 3,90 & 3,76 & 3,81 \\
\hline
\end{tabular}

Source: Authors (2021).

In Table 2 is observed that there are small variations with an increase of $\mathrm{R}_{\mathrm{oc}}$ at each cycle. These values correspond to the amount of oxygen required to completely convert the fuel into $\mathrm{CO}_{2}$ and $\mathrm{H}_{2} \mathrm{O}$. Wang et al. (2017) investigated the $\mathrm{R}_{\mathrm{oc}}$ of an oxygen carrier prepared via the impregnation method with a $40 \%$ wt. copper oxide supported on natural porous material (olivine - $\mathrm{CuO}$ /Olivine), achieving a maximum value of $3.59 \%$ in its tenth cycle of the CLC process, concluding that CLC tests 
weakly affected oxygen carrying capacity (Wang et al., 2017). This result is higher than $\mathrm{Cu}-\mathrm{K} \mathrm{R}_{\mathrm{oc}}$, but lower than $\mathrm{Cu}-\mathrm{D}$ in the third cycle, emphasizing that there is a lower percentage of $\mathrm{CuO}$ impregnated in these carriers.

\subsection{Characterizations of the oxygen carriers}

The XRD patterns corresponding to the in natura, kaolin and diatomite supports are shown in Figure 5.

Figure 5. X-ray diffractograms of kaolin and diatomite supports.
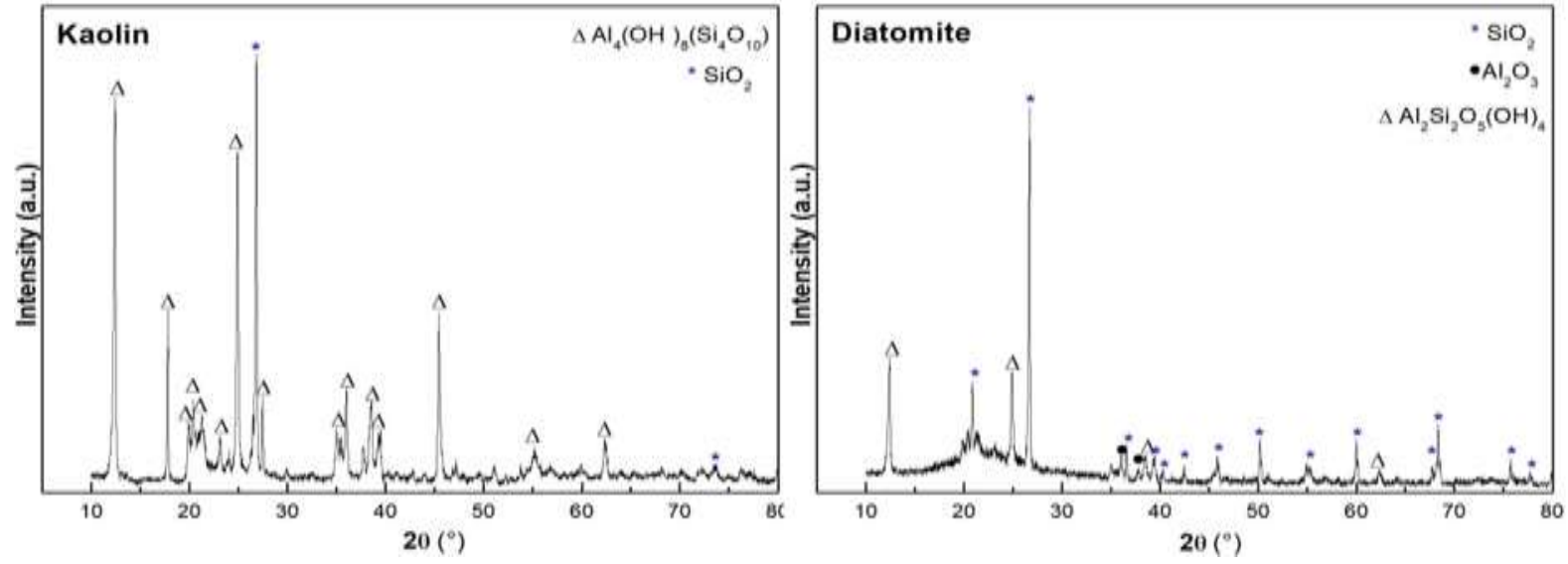

Source: Authors (2021).

According to Figure 5, the kaolin sample showed main crystalline phases for kaolinite $\left(\mathrm{Al}_{4}(\mathrm{OH})_{8}\left(\mathrm{Si}_{4} \mathrm{O}_{10}\right)\right.$ - ICSD 063316), with the main peak at $25^{\circ}$, and silica $\left(\mathrm{SiO}_{2}\right.$ - ICSD 062404) with the main peak at $26.57^{\circ}$. In the diatomite sample, the silica phase $\left(\mathrm{SiO}_{2}\right.$ - ICSD 062404) was also detected with considerably higher intensity than the alumina $\left(\mathrm{Al}_{2} \mathrm{O}_{3}\right.$ - ICSD 082504) and aluminosilicate phases $\left(\mathrm{Al}_{2} \mathrm{Si}_{2} \mathrm{O}_{5}(\mathrm{OH})_{4}-\mathrm{ICSD}\right)$.

An X-ray Diffraction analysis and fresh oxygen carrier patterns reduced to $10 \% \mathrm{H}_{2}$ gas and oxidized (after the third thermobalance cycle) are shown in Figure 6 to understand the reaction pathways of $\mathrm{Cu}$ oxide supported on natural materials (kaolin and diatomite).

The diffractograms of the fresh oxygen carrier particles (Figure 6) revealed the presence of $\mathrm{CuO}$ (ICSD 087124) as the main active phase with higher intensity peaks at $35.54^{\circ}$ and $38.69^{\circ}$. The inert $\mathrm{SiO}_{2}$ (ICSD 062404) and $\mathrm{Al}_{2} \mathrm{SiO}_{5}$ (ICSD 100451) phases were also identified in $\mathrm{Cu}-\mathrm{K} \mathrm{OC}$. The calcination temperature $\left(1100{ }^{\circ} \mathrm{C}\right)$ to obtain this oxygen carrier caused the kaolinite to dehydrate, converting it to matecaulinite $\left(\mathrm{Al}_{2} \mathrm{O}_{3} \cdot 2 \mathrm{SiO}_{2}\right)$ when it reached temperatures above $510^{\circ} \mathrm{C}$; while it favored the formation of $\mathrm{Al}_{2} \mathrm{SiO}_{5}$ aluminosilicate above $900{ }^{\circ} \mathrm{C}$, according to reaction 12. It is observed that the $\mathrm{Cu}-\mathrm{K}$ sample did not show interaction phases between $\mathrm{CuO}$ and $\mathrm{SiO}_{2}$ present in kaolin, otherwise this interaction could result in a reduction of the oxygen carrying capacity $\left(\mathrm{R}_{\mathrm{oc}}\right)$ of this material (Song et al., 2014). Inert phases were also identified as $\mathrm{SiO}_{2}$ (ICSD 062404) and $\mathrm{Al}_{2} \mathrm{O}_{3}$ (ICSD 082504) in the Cu-D OC diffractogram, and the reaction temperature to obtain this oxygen carrier did not cause the formation of copper silicates and aluminates, which could result in a negative effect on their reactivity in CLC processes. These natural inert supports act to increase the mechanical strength, maintaining the porous structure of the particles at high temperatures, and the aluminosilicate can give a high modulus of rupture and chemical stability to the $\mathrm{Cu}-\mathrm{K}$ oxygen carrier (García-Labiano et al., 2004; Ma et al., 2017).

\footnotetext{
$\mathrm{Al}_{2} \mathrm{O}_{3} \cdot 2 \mathrm{SiO}_{2} \stackrel{>900^{\circ} \mathrm{C}}{\longrightarrow} \mathrm{Al}_{2} \mathrm{SiO}_{5}+\mathrm{SiO}_{2}$
} 
Figure 6. X-ray diffractogram of fresh $\mathrm{Cu}-\mathrm{K}$ and $\mathrm{Cu}-\mathrm{D}$ reduced to $10 \% \mathrm{H}_{2}$ and oxidized after thermobalance testing.
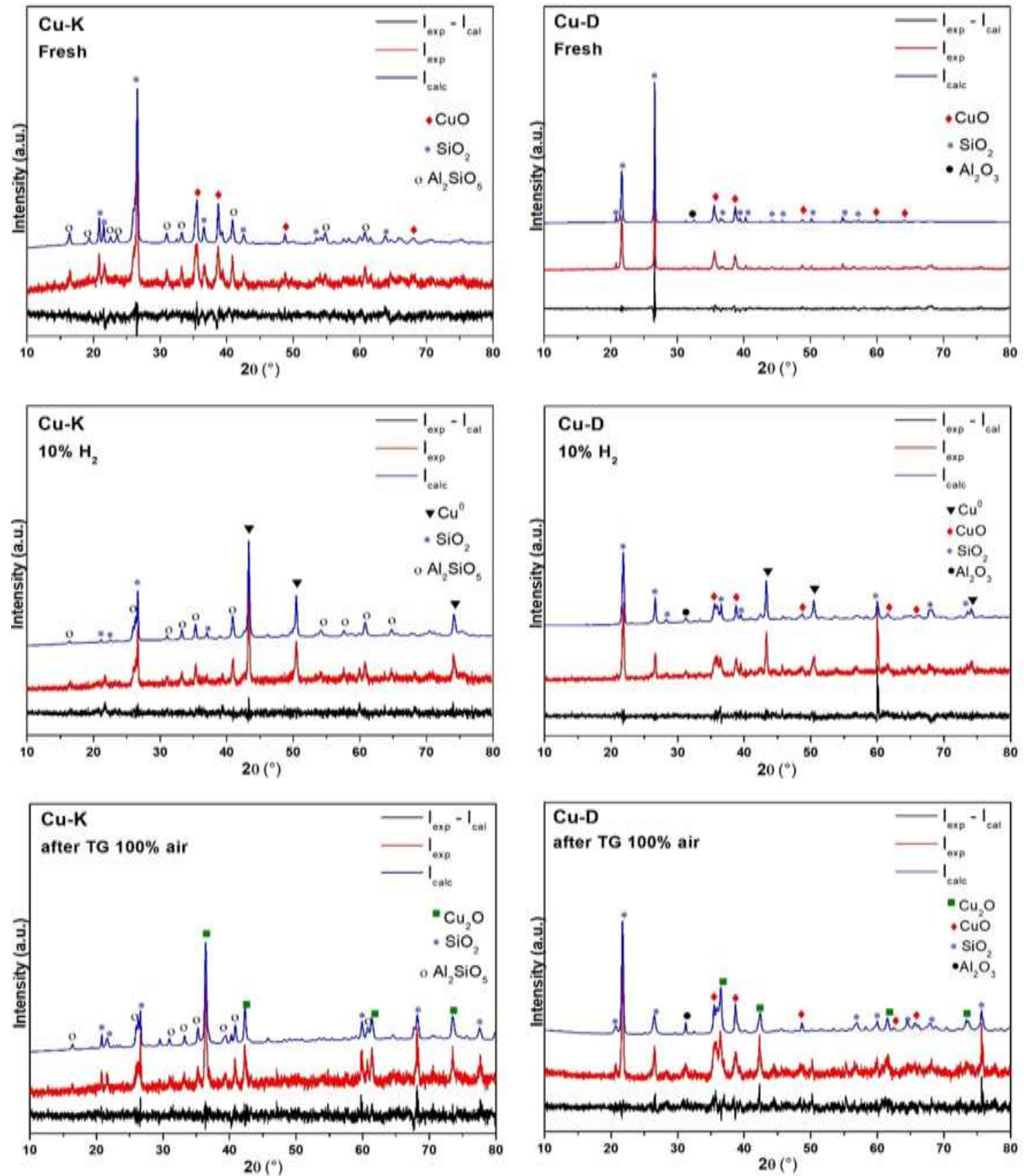

Source: Authors (2021).

The diffractograms of the oxygen carrier particles reduced to $10 \% \mathrm{H}_{2}$ gas indicate that the $\mathrm{Cu}-\mathrm{K}$ particles underwent uniform reduction reactions and all $\mathrm{CuO}$ was reduced to $\mathrm{Cu}^{0}$ with a peak peak of $43.50^{\circ}$, conforming to reaction 13 . In fact, it does not exclude the possibility that $\mathrm{Cu}_{2} \mathrm{O}$ exists as an intermediate phase in $\mathrm{CuO}$ reduction phase transformations under $\mathrm{CLC}$ conditions. However, the diffractogram of the reduced $\mathrm{Cu}-\mathrm{D}$ particles shows that this reducing condition was not sufficient for the complete reduction of $\mathrm{CuO}$ to $\mathrm{Cu}_{2} \mathrm{O}$ and/or $\mathrm{Cu}^{0}$. Table 3 shows the percentage of the crystalline phases of the carriers reduced to $10 \% \mathrm{H}_{2}$ through the Rietveld refinement and proves the conversion of each phase. 
After the third thermobalance cycle in the reoxidation step, in the diffractograms it is noted that the reduced $\mathrm{Cu}-\mathrm{K} \mathrm{OC}$ particles did not present the fully oxidized copper oxide $(\mathrm{CuO})$ phase. For the $\mathrm{Cu}-\mathrm{D} \mathrm{OC}$, a mixture of $\mathrm{Cu}_{2} \mathrm{O}$ and $\mathrm{CuO}$ with $4.90 \%$ wt. and $11.66 \%$ wt. was identified respectively, according to the data from the Rietveld refinement presented in Table 3. However, the reactivity tests show increased reactivity with increasing number of cycles, so $\mathrm{Cu}_{2} \mathrm{O}$ reoxidation does not negatively affect its conversion. This fact may be related to the high reduction rate providing a good final $\mathrm{Cu}_{2} \mathrm{O}$ phase conversion (Pio et al., 2018).

Table 3 - Percentage of phases in OCs calcined at $1100^{\circ} \mathrm{C}(1 \mathrm{~h})$ obtained by the Rietveld refinement.

\begin{tabular}{|c|c|c|c|c|c|c|c|c|c|}
\hline \multirow[t]{2}{*}{$\mathrm{OC}$} & \multicolumn{6}{|c|}{ Phases (\% wt.) } & \multirow[t]{2}{*}{$\begin{array}{c}\text { Crystallinity } \\
(\%)\end{array}$} & \multicolumn{2}{|c|}{$\begin{array}{l}\text { Refinament } \\
\text { parameters }\end{array}$} \\
\hline & $\mathrm{CuO}$ & $\mathrm{Cu}^{0}$ & $\mathrm{Cu}_{2} \mathrm{O}$ & $\mathrm{Al}_{2} \mathrm{O}_{3}$ & $\mathrm{SiO}_{2}$ & $\mathrm{Al}_{2} \mathrm{SiO}_{5}$ & & Sig & $\begin{array}{l}\text { Rwp } \\
(\%)\end{array}$ \\
\hline $\begin{array}{c}\text { Cu-K } \\
\text { (Fresh) }\end{array}$ & 12.29 & - & - & - & 34.66 & 53.05 & 54.77 & 1.28 & 11.92 \\
\hline $\begin{array}{c}\mathrm{Cu}-\mathrm{K} \\
\left(10 \% \mathbf{H}_{2}\right)\end{array}$ & - & 23.59 & - & - & 22.17 & 54.24 & 59.77 & 1.13 & 13.39 \\
\hline $\begin{array}{c}\text { Cu-K } \\
\text { (After TG) }\end{array}$ & - & - & 24.89 & - & 18.00 & 57.11 & 73.22 & 1.21 & 14.51 \\
\hline $\begin{array}{c}\text { Cu-D } \\
\text { (Fresh) }\end{array}$ & 20.34 & - & - & 2.00 & 77.66 & - & 79.01 & 1.71 & 14.05 \\
\hline $\begin{array}{c}\text { Cu-D } \\
\left(10 \% \mathrm{H}_{2}\right)\end{array}$ & 9.91 & 12.02 & - & 12.41 & 65.66 & - & 77.51 & 1.28 & 14.41 \\
\hline $\begin{array}{c}\text { Cu-D } \\
\text { (After TG) }\end{array}$ & 11.66 & - & 4.90 & 6.87 & 76.57 & - & 81.39 & 1.26 & 12.80 \\
\hline
\end{tabular}

Source: Authors (2021).

In addition, according to the concentration of the crystalline phase obtained by the refinement (as shown in Table 3), different percentages of reducible $\mathrm{Cu}$ under CLC conditions present in the samples can refer to an activation step of the materials in the first cycle, so that only the three cycles cannot indicate reliable stability.

Table 4 shows the mechanical strength of the $\mathrm{Cu}-\mathrm{D}$ and $\mathrm{Cu}-\mathrm{K}$ particles after being calcined at $1100{ }^{\circ} \mathrm{C}$. According to Adanez et al. (2004), the resistance in Newton (N) of the particles depends on the type of metal oxide used as the active phase, its concentration, the support used and the sintering temperature (Adánez et al., 2004). High sintering temperatures generally increase the strength of oxygen carriers. However, this temperature should be limited for copper as it may cause it to melt. 
Table 4. Mechanical strength and standard deviation of oxygen carriers at $1100{ }^{\circ} \mathrm{C}$.

\begin{tabular}{ccc}
\hline OCs & Mechanical strength $(\mathbf{N})$ & Standard deviation \\
\hline $\mathrm{Cu}-\mathrm{D}$ & 2,96 & 0,93 \\
$\mathrm{Cu}-\mathrm{K}$ & 2,33 & 0,81 \\
\hline
\end{tabular}

Source: Authors (2021).

The Table 4 reports that copper oxide exhibits appreciable mechanical strength when using $\mathrm{SiO}_{2}$ as a support. According to Johansson et al. (2004), oxygen carriers with mechanical strength less than 1.0N are unsuitable for use in CLC processes (Johansson et al., 2004).

Thus, it is possible to evidence that the optimization of the mechanical strength of $\mathrm{Cu}-\mathrm{D}$ and $\mathrm{Cu}-\mathrm{K}$ particles is the result of the presence of aluminosilicates acting as a support and control for the percentage of active phase impregnated (less than $21 \%$ wt. of $\mathrm{CuO}$ ), favoring the calcination of the $\mathrm{OCs}$ at $1100{ }^{\circ} \mathrm{C}$. $\mathrm{Cu}-\mathrm{D}$ has higher mechanical strength because it has a higher $\mathrm{CuO}$ concentration compared to $\mathrm{Cu}-\mathrm{k}$. Therefore, both $\mathrm{Cu}$-based oxygen carriers have excellent mechanical strength to be applied in chemical recirculation processes.

Figure 7. Temperature-Programmed Reduction of the Oxygen Carriers: $\mathrm{Cu}-\mathrm{K}$ and $\mathrm{Cu}-\mathrm{D}$.

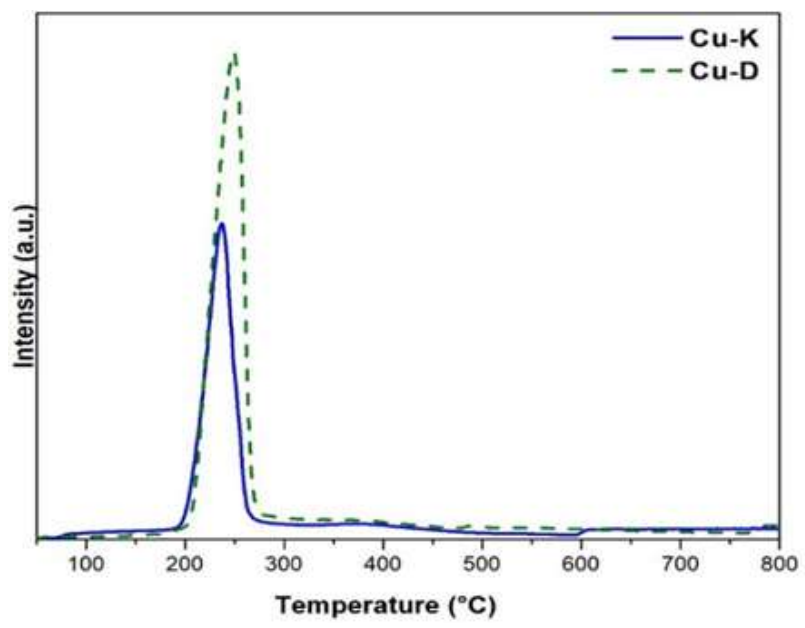

Source: Authors (2021).

Figure 7 shows the $\mathrm{H}_{2}$-TPR profiles of $\mathrm{Cu}$ oxygen carriers. It is observed that there is a single apparent peak in the temperature range of $190-380{ }^{\circ} \mathrm{C}$ during the reduction of $\mathrm{Cu}-\mathrm{K}$ and $\mathrm{Cu}-\mathrm{D}$ particles. This peak can be attributed to the reduction of a single $\mathrm{Cu}$ species $\left(\mathrm{Cu}^{2+} \rightarrow C u^{0}\right)$, in accordance with the symmetrical characteristic of the peaks, with a maximum consumption around $240{ }^{\circ} \mathrm{C} . \mathrm{H}_{2}$ consumption was more intense in $\mathrm{Cu}-\mathrm{D}\left(43.84 \mathrm{~cm}^{3} / \mathrm{g}\right)$ compared to the reduction of $\mathrm{Cu}-\mathrm{K}$ particles $\left(27.77 \mathrm{~cm}^{3} / \mathrm{g}\right)$ due to the higher percentage of copper oxide present $(20.34 \%)$, and its wider peak may be associated with a more difficult reduction.

The surface and particle morphology of $\mathrm{Cu}-\mathrm{K}$ and $\mathrm{Cu}-\mathrm{D}$ oxygen carriers were assessed by Scanning Electron Microscopy (SEM), as shown in Figure 8 and Figure 9, respectively. 
Figure 8. X-ray Dispersive Energy Scanning Electron Microscopy (SEM/EDS) of the surface of the: a) $\mathrm{Cu}-\mathrm{K}$ and b) $\mathrm{Cu}-\mathrm{D}$.
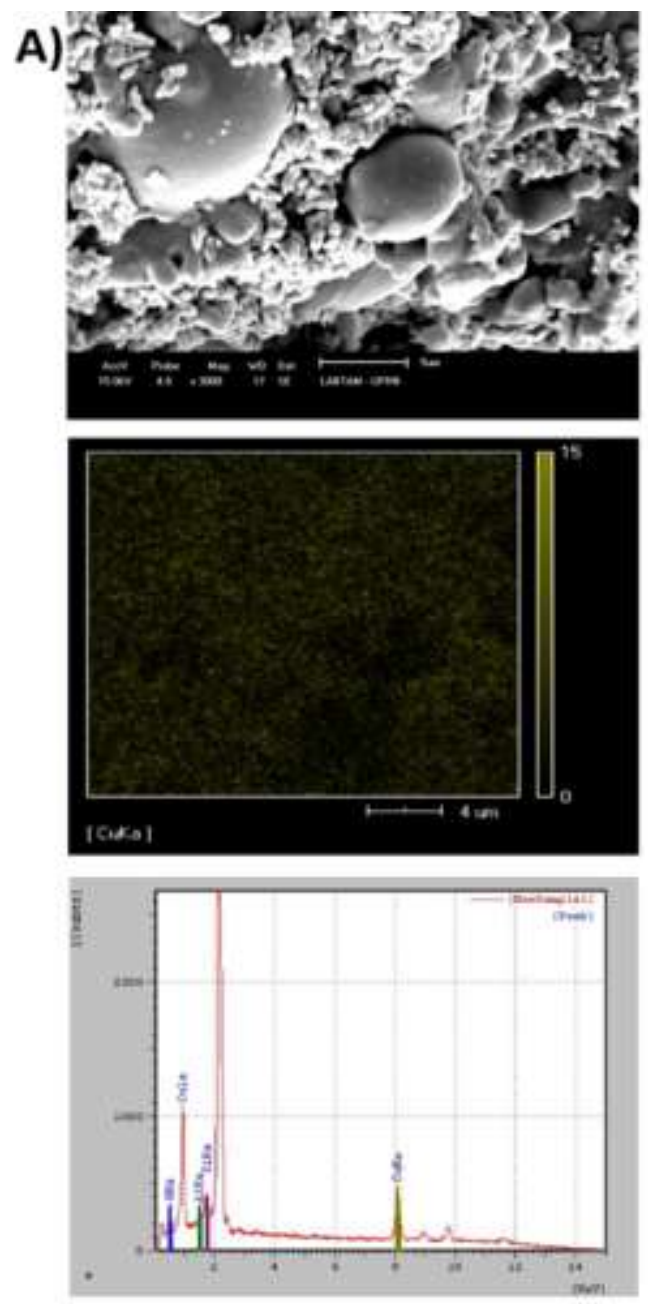
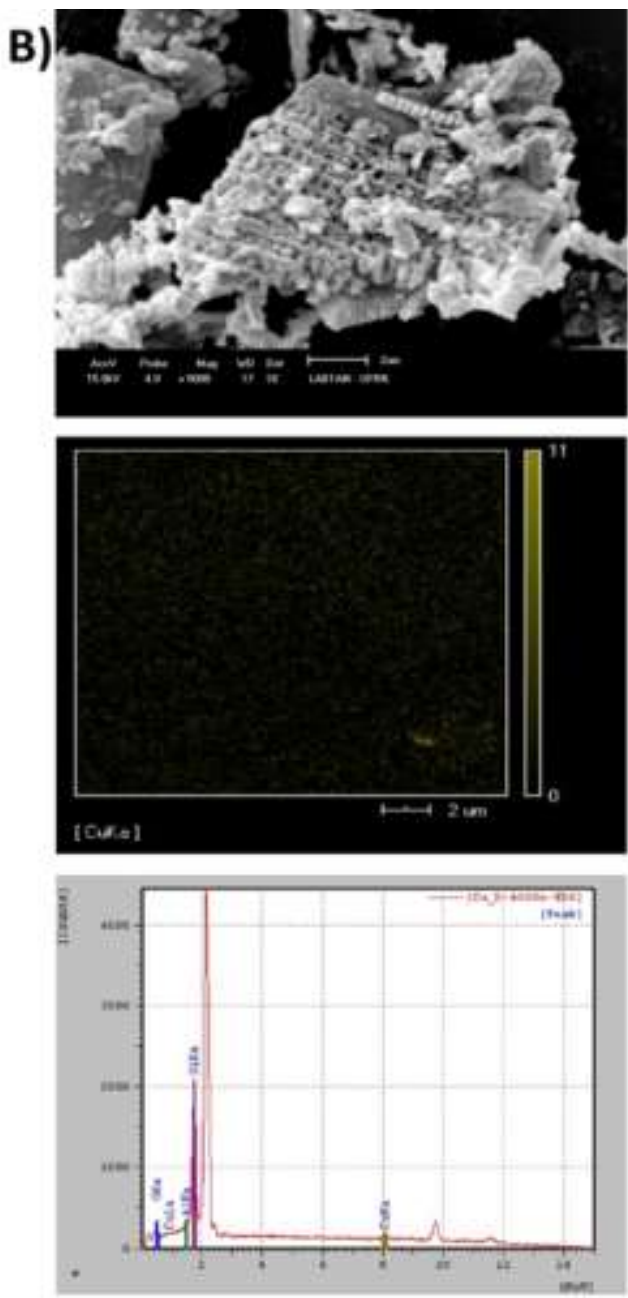

Source: Authors (2021).

As shown in Figures $8 a$ and $b$, the $\mathrm{Cu}-\mathrm{K}$ surface (Figure $8 a$ ) has a smooth surface with different sized grains and irregularly shaped $\mathrm{CuO}$ particles deposited, and the $\mathrm{Cu}-\mathrm{D}$ surface (Figure $8 b$ ) is morphologically shaped in the form plates showing well-defined pores with the $\mathrm{CuO}$ particles blocking and coating the porous structure. These characteristics are derived from the morphology of the natural kaolin and diatomite supports (Johansson et al., 2004; Maia et al., 2019; Mebreka et al., 2019). It is possible to verify that there is uniform distribution of irregularly shaped $\mathrm{CuO}$ particles through the chemical mapping of both surfaces. The uniformity of distribution plays an important role as it favors an increase in surface area, making copper oxide more available on the surface. The presence of $\mathrm{Si}, \mathrm{Al}, \mathrm{Cu}$ and $\mathrm{O}$ elements was identified, being consistent with the of XRF and XRD results. 
Figure 9. Particle Scanning Electron Microscopy of: a) $\mathrm{Cu}-\mathrm{K}$ and b) $\mathrm{Cu}-\mathrm{D}$.
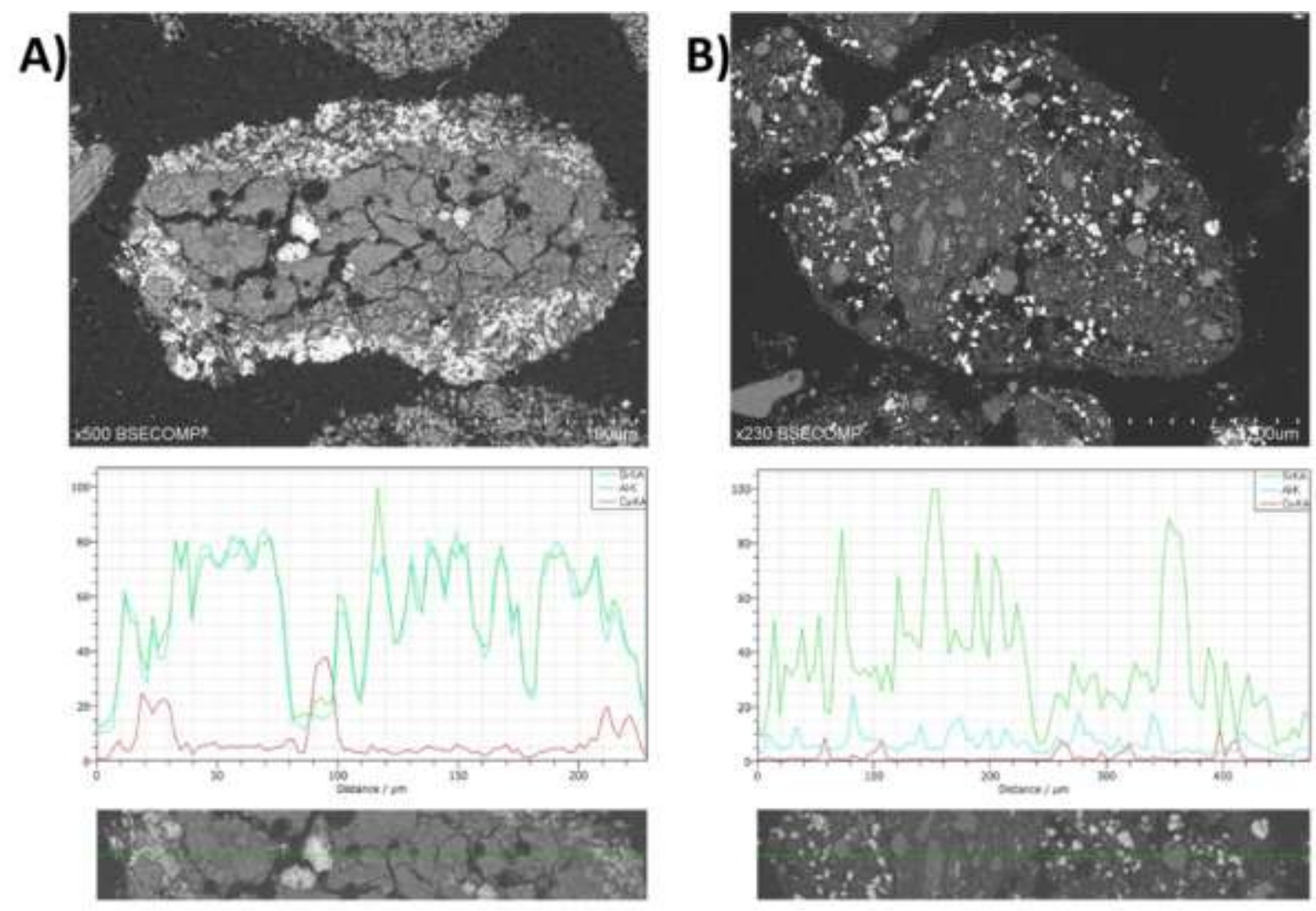

Source: Authors (2021).

Figures $9 a$ and $b$ show that there are groups of $\mathrm{CuO}$ particles within the $\mathrm{Cu}-\mathrm{K}$ and $\mathrm{Cu}-\mathrm{D}$ oxygen carrier particles respectively, not showing a uniform distribution of the active phase. However, a study by Wang et al. (2017) reveals that the accumulation of $\mathrm{CuO}$ particles gradually disappears with an increasing number of redox cycles (Wang et al., 2017). This fact contributes to the increased reactivity of oxygen carriers over the course of reaction cycles.

It was also observed (in Figure 9) that there is a lower $\mathrm{CuO}$ content on the $\mathrm{Cu}-\mathrm{D}$ particle surface compared to the $\mathrm{Cu}$ $\mathrm{K}$ particle surface, which induces that copper oxide has penetrated the porous structure of the support. Therefore, although $\mathrm{Cu}$ $\mathrm{D}$ has a higher $\mathrm{CuO}$ content, a less amount which is present in $\mathrm{Cu}-\mathrm{K}$ is available to participate in CLC reactions. However, it is important to highlight that the Cu-D reactivity test with $\mathrm{CH}_{4}$ and $\mathrm{H}_{2}$ in TGA showed that the percentage of active phase present was ideal to maintain its reactivity during the cycles presented.

\section{Conclusion}

Reactivities during the reduction and oxidation reactions of $\mathrm{Cu}$-based oxygen carriers $(\mathrm{CuO})$ supported on natural diatomite and kaolin materials were analyzed by thermogravimetry (TGA) and their physicochemical properties by XRD, SEM-EDS, and TPR. The impregnation of CuO particles in the diatomite and kaolin supports did not result in forming copper silicates and aluminates. Moreover, they showed appropriate mechanical strength and uniform distribution of the $\mathrm{CuO}$ particles on the surface of the oxygen carriers. Both showed increased reactivity and oxygen carrying capacity when submitted to three redox cycles, but their stability was not reached after the third cycle. This reveals that there are changes in the structure of the oxygen carriers during this reaction period. The regeneration of $\mathrm{Cu}-\mathrm{K}$ after the third cycle with $\mathrm{CH}_{4}$ did not lead to the formation of fully oxidized copper oxide and a mixture of $\mathrm{Cu}_{2} \mathrm{O}$ and $\mathrm{CuO}$ was identified in $\mathrm{Cu}-\mathrm{D}$, but failure to obtain fully oxidized $\mathrm{CuO}$ did not affect its reactivity during the cycles. Reactivity tests with $\mathrm{H}_{2}$ gas as the fuel showed a higher conversion 
rate and greater constancy between cycles for both oxygen carriers. It was observed that $\mathrm{Cu}-\mathrm{D}$ presented a higher reactivity and reaction rate in the reduction and oxidation steps, which can be attributed to the pore structure of diatomite, the chemical composition and the resulting interaction between $\mathrm{CuO}$ and the support. The percentage of reducible $\mathrm{CuO}$ present in $\mathrm{Cu}-\mathrm{D}$ during the reactivity test with $\mathrm{H}_{2}$ as fuel gas was ideal for achieving high solids conversion, a greater tendency to stability and a higher reaction rate.

For future work, we can develop a new synthesis route, by which it will improve the mechanical resistance of the oxygen carriers studied in this work. With the improvement of the mechanical resistance of these materials we will have greater stability of the samples during the accomplishment of the multiple redox cycles.

\section{Acknowledgments}

The authors wish to thank the Brazilian Federal agencies CAPES (National Council for the improvement of Higher Education Personnel) and CNPq (National Conncil for Scientific and Technological Development) for financial support, and the Instituto de Carboquímica (ICB-CSIC-Spain) for reactivity tests and characterizations.

\section{References}

Abad, A., Cuadrat, A., Mendiara, T., García-Labiano, F., Gayán, P., De Diego, L. F., \& Adánez, J. (2012). Low-cost Fe-based oxygen carrier materials for the iG-CLC process with coal. 2. Industrial and Engineering Chemistry Research, 51(50), 16230-16241. https://doi.org/10.1021/ie302158q.

Adánez-Rubio, I., Arjmand, M., Leion, H., Gayán, P., Abad, A., Mattisson, T., \& Lyngfelt, A. (2013). Investigation of combined supports for cu-based oxygen carriers for chemical-looping with oxygen uncoupling (CLOU). Energy and Fuels, 27(7), 3918-3927. https://doi.org/10.1021/ef401161s.

Adánez-Rubio, I., Gayán, P., García-Labiano, F., de Diego, L. F., Adánez, J., \& Abad, A. (2011). Development of CuO-based oxygen-carrier materials suitable for Chemical-Looping with Oxygen Uncoupling (CLOU) process. Energy Procedia, 4, 417-424. https://doi.org/10.1016/J.EGYPRO.2011.01.070.

Adánez-Rubio, I., Izquierdo, M. T., Abad, A., Gayán, P., de Diego, L. F., \& Adánez, J. (2017). Spray granulated Cu-Mn oxygen carrier for chemical looping with oxygen uncoupling (CLOU) process. International Journal of Greenhouse Gas Control, 65, 76-85. https://doi.org/10.1016/J.IJGGC.2017.08.021.

Adánez-Rubio, I., Pérez-Astray, A., Mendiara, T., Izquierdo, M. T., Abad, A., Gayán, P., ... Adánez, J. (2018). Chemical looping combustion of biomass: CLOU experiments with a Cu-Mn mixed oxide. Fuel Processing Technology, 172(January), 179-186. https://doi.org/10.1016/j.fuproc.2017.12.010.

Adanez, J., Abad, A., Garcia-Labiano, F., Gayan, P., \& De Diego, L. F. (2012). Progress in chemical-looping combustion and reforming technologies. Progress in Energy and Combustion Science, 38(2), 215-282. https://doi.org/10.1016/j.pecs.2011.09.001.

Adánez, J., Abad, A., Mendiara, T., Gayán, P., de Diego, L. F., \& García-Labiano, F. (2018). Chemical looping combustion of solid fuels. Progress in Energy and Combustion Science, Vol. 65, pp. 6-66. https://doi.org/10.1016/j.pecs.2017.07.005.

Adánez, J., De Diego, L. F., García-Labiano, F., Gayán, P., Abad, A., \& Palacios, J. M. (2004). Selection of oxygen carriers for chemical-looping combustion. Energy and Fuels, 18(2), 371-377. https://doi.org/10.1021/ef0301452.

de Diego, L. F., Gayán, P., García-Labiano, F., Celaya, J., Abad, A., \& Adánez, J. (2005). Impregnated CuO/Al2O3 oxygen carriers for chemical-looping combustion: Avoiding fluidized bed agglomeration. Energy and Fuels, 19(5), 1850-1856. https://doi.org/10.1021/ef050052f.

De Freitas, V. A. A., Lima, J. S. V., \& Da Couceiro, P. R. C. (2011). Caracterização e análise estrutural da hidroxisodalita sintetizada a partir de amostras de solo Amazônico. Ceramica, 57(343), 281-287.

Fernandes, T., Hacon, S. S., Novais, J. W. Z., Siguarezi, S. B., Silva, C. J., Alcântara, L. C. S., Curvo, A. D., Fernandes, T. (2019). Poluição do ar e efeitos na saúde de crianças na Amazônia paraense: uma análise bibliométrica. Pesquisa, Sociedade e Desenvolvimento, 8 (4), e4984907. http://dx.doi.org/10.33448/rsdv8i4.907.

Forero, C. R., Gayán, P., de Diego, L. F., Abad, A., García-Labiano, F., \& Adánez, J. (2009). Syngas combustion in a 500 Wth Chemical-Looping Combustion system using an impregnated Cu-based oxygen carrier. Fuel Processing Technology, 90(12), 1471-1479. https://doi.org/10.1016/j.fuproc.2009.07.001.

García-Labiano, F., de Diego, L. F., Adánez, J., Abad, A., \& Gayán, P. (2004). Reduction and Oxidation Kinetics of a Copper-Based Oxygen Carrier Prepared by Impregnation for Chemical-Looping Combustion. Industrial \& Engineering Chemistry Research. https://doi.org/10.1021/ie0493311.

Gayán, P., Adánez-Rubio, I., Abad, A., De Diego, L. F., García-Labiano, F., \& Adánez, J. (2012). Development of Cu-based oxygen carriers for ChemicalLooping with Oxygen Uncoupling (CLOU) process. Fuel, 96, 226-238. https://doi.org/10.1016/j.fuel.2012.01.021.

Gomes, D. S., Barbosa, A. S., Santos, T. M., Santos, S. K., Sales Silva, J. H. C., Aquino, I. S. (2021). Cinética de liberação de CO2 e decomposição da fitomassa em sistemas de uso e manejo do solo. Pesquisa, Sociedade e Desenvolvimento, 10 (1). e9810111413. http://dx.doi.org/10.33448/rsd-v10i1.11413.

Johansson, M., Mattisson, T., \& Lyngfelt, A. (2004). Investigation of FeO with MgAlO for Chemical-Looping Combustion Investigation of Fe2O3 with MgAl 2 O 4 for Chemical-Looping Combustion. 43(22), 6978-6987. https://doi.org/10.1021/ie049813c. 
Liu, J., Zheng, C., Yue, J., \& Xu, G. (2019). Synthesis, characterization and catalytic methanation performance of modified kaolin-supported Ni-based catalysts. Chinese Journal of Chemical Engineering. https://doi.org/10.1016/J.CJCHE.2019.04.009.

Ma, J., Tian, X., Zhao, H., Bhattacharya, S., Rajendran, S., \& Zheng, C. (2017). Investigation of Two Hematites as Oxygen Carrier and Two Low-Rank Coals as Fuel in Chemical Looping Combustion. Energy and Fuels, 31(2), 1896-1903. https://doi.org/10.1021/acs.energyfuels.6b02101.

Maia, A. Á. B., Dias, R. N., Angélica, R. S., \& Neves, R. F. (2019). Influence of an aging step on the synthesis of zeolite NaA from Brazilian Amazon kaolin waste. Journal of Materials Research and Technology, 8(3), 2924-2929. https://doi.org/10.1016/j.jmrt.2019.02.021 .

McGlashan, N., Shah, N., Caldecott, B., \& Workman, M. (2012). High-level techno-economic assessment of negative emissions technologies. Process Safety and Environmental Protection. https://doi.org/10.1016/j.psep.2012.10.004.

Mebreka, A., \& , Hadda Rezzaga, Sihem Benayachea, Afef Azzia, Yasmina Taïbib, Sabrina Ladjamaa, Naima Touatia, Azzedine Grida, S. B. (2019). Effect of chamotte on the structural and microstructural characteristics of mullite elaborated via reaction sintering of Algerian kaolin.

Mendiara, T., Pérez-Astray, A., Izquierdo, M. T., Abad, A., de Diego, L. F., García-Labiano, F., \& Adánez, J. (2018). Chemical Looping Combustion of different types of biomass in a 0.5 kWth unit. Fuel, 211, 868-875. https://doi.org/10.1016/j.fuel.2017.09.113.

Oliveira, M M., Esteves, P. M. S. V., Baía, S. R. D., Dantas, N. S., Silva, V. F. (2020). Análise da produção científica internacional sobre mudanças climáticas e poluição do ar. Pesquisa, Sociedade e Desenvolvimento,9 (10), e1609108314. http://dx.doi.org/10.33448/rsd-v9i10.8314.

San Pio, M. A., Gallucci, F., Roghair, I., \& van Sint Annaland, M. (2017). On the mechanism controlling the redox kinetics of Cu-based oxygen carriers. Chemical Engineering Research and Design, 124, 193-201. https://doi.org/10.1016/j.cherd.2017.06.019.

San Pio, M. A., Martini, M., Gallucci, F., Roghair, I., \& van Sint Annaland, M. (2018). Kinetics of CuO/SiO2 and CuO/Al2O3 ox ygen carriers for chemical looping combustion. Chemical Engineering Science, 175, 56-71. https://doi.org/10.1016/j.ces.2017.09.044.

San Pio, M. A., Roghair, I., Gallucci, F., \& van Sint Annaland, M. (2016). Investigation on the decrease in the reduction rate of oxygen carriers for chemical looping combustion. Powder Technology, 301, 429-439. https://doi.org/10.1016/J.POWTEC.2016.06.031.

Santos, K. C. V, Gonçalves, W. P., Silva, V. J., Santana, L. N. L., \& Lira, H. L. (2017). Formação de Mulita a Partir de Composições de Caulim e Alumina com Diferentes Tamanhos de Partículas. Revista Eletrônica de Materiais e Processos, 3(2016), 136-142.

Song, H., Shah, K., Doroodchi, E., Wall, T., \& Moghtaderi, B. (2014). Reactivity of Al2O3- or SiO2-Supported Cu-, Mn-, and Co-based oxygen carriers for chemical looping air separation. Energy and Fuels, 28(2), 1284-1294. https://doi.org/10.1021/ef402268t.

Takht, M., \& Saeed, R. (2014). Carbon dioxide capture and utilization in petrochemical industry: potentials and challenges. (27), 63-77. https://doi.org/10.1007/s13203-014-0050-5.

Van Garderen, Noémie, Clemens, F. J., Kaufmann, J., Urbanek, M., Binkowski, M., Graule, T., \& Aneziris, C. G. (2012). Pore analyses of highly porous diatomite and clay based materials for fluidized bed reactors. Microporous and Mesoporous Materials, 151, $255-263$. https://doi.org/10.1016/J.MICROMESO.2011.10.028.

Van Garderen, Noemie, Otal, E. H., Aneziris, C. G., Graule, T., \& Clemens, F. J. (2014). Influence of porous substrate on cop per based oxygen carrier efficiency for chemical-looping combustion. Microporous and Mesoporous Materials, 190, 362-370. https://doi.org/10.1016/j.micromeso.2014.02.017.

Wang, K., Yan, X., \& Komarneni, S. (2018). CO 2 Adsorption by Several Types of Pillared Montmorillonite Clays. Applied Petrochemical Research, 8(3), 173-177. https://doi.org/10.1007/s13203-018-0206-9.

Wang, P., Means, N., Howard, B. H., Shekhawat, D., \& Berry, D. (2018). The reactivity of CuO oxygen carrier and coal in Chemical-Looping with Oxygen Uncoupled (CLOU) and In-situ Gasification Chemical-Looping Combustion (iG-CLC). Fuel, 217(January), 642-649. https://doi.org/10.1016/j.fuel.2017.12.102.

Wang, X., Xu, T., Jin, X., Hu, Z., Liu, S., Xiao, B., \& Hu, M. (2017). CuO supported on olivine as an oxygen carrier in chemical looping processes with pine sawdust used as fuel. Chemical Engineering Journal. https://doi.org/10.1016/j.cej.2017.07.175.

Zhang, L., Li, K., Gu, Z., Zhu, X., Wei, Y., Li, L., \& Wang, H. (2019). Iron-rich copper ore as a promising oxygen carrier for chemical looping combustion of methane. Journal of the Taiwan Institute of Chemical Engineers, 101, 204-213. https://doi.org/10.1016/j.jtice.2019.04.053. 